\title{
DUELO DE MASCULINIDADES: GÊNERO, CASAMENTO E ADULTÉRIO CLERICAL NO REINO DE LEÃO E CASTELA, SÉCULO XIII1
}

\section{FIGHT OF MASCULINITIES: GENDER, MARRIAGE AND CLERICAL ADULTERY IN THE KINGDOM OF CASTILE AND LEON, THIRTEENTH CENTURY}

Marcelo Pereira Lima²

\begin{abstract}
RESUMO: No final de um dos seus artigos clássicos, a autora Joan Scott havia sugerido que era fundamental sabermos como as instituições sociais incorporam o gênero nos seus pressupostos e nas suas organizações. Seguindo essa agenda, a interseção entre a História Institucional do Direito e os Estudos de Gênero, apesar dos impasses e diferenças, e da multiplicidade de orientações teóricas e metodológicas, pode ser um espaço profícuo na renovação de ambos os campos historiográficos. Neste artigo, temos como objetivo central testar os limites e possibilidades dessa relação, focalizando principalmente a maneira como o casamento e 0 adultério clericais foram (des)articulados às diretrizes de gênero. Como se trata de um estudo preliminar, concentraremos nossa atenção sobre os complexos processos discursivo-institucionais de $\mathrm{d}($ en)ominação sobre as masculinidades clericais representadas, basicamente, em algumas legislações elaboradas no reino de Castela e Leão, do século XIII, sobretudo no período de governo de Afonso X (1252-1284).
\end{abstract}

PALAVRAS-CHAVE: Gênero; Masculinidades; Clerical Adultério.

ABSTRACT: At the end of one of his classic articles, the author Joan Scott had suggested that it was essential to know how social institutions incorporate the gender in their assumptions and their organizations. Following this agenda, the intersection between the Institutional History of Law and Gender Studies, despite the differences and impasses, and the multiplicity of theoretical and methodological backgrounds, may be a fruitful area to renovate both fields of historiography. In this article, we tried to test the limits and possibilities of this relationship, focusing primarily on how clericals marriage and adultery were (dis)articulated for guidelines gender. As this is a preliminary study, we will focus on the complex institutional and discursive processes of domination and denomination on clerical masculinities basically represented in some legislation drawn up in the kingdom of Castile and Leon, of the thirteenth century, especially in the period of government Alfonso X (1252-1284).

KEYWORDS: Gender; Masculinities; Adultery Clerical.

(recebido em 12/01/2013, aprovado em 21/04/2013)

\section{Introdução}

Este texto é parte do Capítulo 3 da minha tese de doutorado, intitulada $O$ gênero do adultério no discurso jurídico do governo de Afonso X (1252-1284), apresentado ao PPGH da UFF no ano de 2010. Ele foi modificado, ampliado e apresentado no XIII Simpósio Nacional da Associação Brasileira de História das Religiões. Religião, Carisma e Poder: as formas da vida religiosa no Brasil, de 29 de maio a 1 de junho de 2012, UFMA em São Luís-MA.

Professor Adjunto I de História Medieval na Universidade Federal da Bahia. Endereço eletrônico: inperpetuum@uol.com.br 
Como aponta a antropóloga Mirian Goldenberg, o que era "visto como um tema menor nas ciências sociais, hoje é um campo fértil de estudos". ${ }^{3}$ Trata-se das masculinidades, em suas múltiplas configurações, que, ao contrário de estar simplesmente em crise, do ponto de vista da análise científica, tornou-se "uma questão a ser pensada e debatida". ${ }^{4}$ Nas últimas décadas, os chamados Men's Studies desenvolveram-se de forma significativa em numerosos ramos de conhecimentos, tais como a Teoria Literária, a Psicologia Social, a Sociologia, a Antropologia, a Ciência Política e, claro, a História. Eles também alcançaram o interesse de públicos não acadêmicos e não-militantes em diversas mídias contemporâneas. ${ }^{5}$ Cada um desses ramos possui horizontes e alcances analíticos diferentes, propondo soluções singulares, divergentes e contraditórias, mas também plurais, convergentes e compatíveis sobre a problemática da(s) masculinidade(s). Todos esses campos de saberes têm se esforçado em desessencializar o que significa ser homem para determinadas pessoas, coletividades e/ou instituições. Até certo ponto, e em alguns campos de saberes, essa desnaturalização do(s) masculino(s) procura prolongar os questionamentos dos Gender Studies ao androcentrismo da produção de conhecimentos acadêmicos e da vida social.

Segundo Anne Pérotin-Dumon, os estudos dos "homens como tais", ou melhor, dos "men as men", diferenciar-se-iam das investigações dedicadas tradicionalmente ao Homem, no singular e com "H" maiúsculo, situando-os na linha dos estudos sobre as mulheres e das reflexões suscitadas sobre a

Cf. GOLDENBERG, M. Masculinidade em crise: novos modelos de "ser homem". Disponivel na Internet $<$ http://miriangoldenberg.com.br/content.php?option=com_content\&task=view\&id=29\&ltemid=95>. Acesso em abril de 2013.

Cf. GOLDENBERG, M. Masculinidade em crise... Op. cit.

Cf. OLIVEIRA, P. P. A construção social da masculinidade. Belo Horizonte: Editora UFMG, Rio de Janeiro: IUPERJ, 2004; SILVA, S. G. A crise da Masculinidade: uma crítica à identidade de Gênero e à Literatura Masculinista. Psicologia, Ciência e Profissão, 2006, 26 (1), 118-131; Masculinidade na História, Psicologia, Ciência e Profissão, 2000, 20 (3), 8-15; CECCARELLI, P. R. A construção da masculinidade, Percurso, São Paulo, Vol. 19, p.4956, 1998; DAMATTA, R. Tem pente aí?: reflexões sobre a identidade masculina. In: CALDAS, D. (org). Homens. São Paulo: Ed. Senac, 1997; FREYRE, G. Modos de homem. Modas de mulher. Rio de Janeiro: Record, 1986; GOLDENBERG, M. Ser homem, ser mulher: dentro e fora do casamento. Rio de Janeiro: Revan, 1991; __. . A Outra: estudos antropológicos sobre a identidade da amante do homem casado. Rio de Janeiro: Record, 1997; Os Novos Desejos. Rio de Janeiro: Record, 2000; KIMMEL, M. A produção simultânea de masculinidades hegemônicas e subalternas. Horizontes antropológicos 9 (4), 1998, p. 103-17; KIMMEL, M. \& MESSNER, M. Men's Lives. Boston, Allyn and Bacon, 1994; RAMOS, M. S. Um olhar sobre o masculino: reflexões sobre os papéis e representações sociais do homem na atualidade. In: GOLDENBERG, M. (org). Os Novos Desejos. Rio de Janeiro: Record, 2000; BOURDIEU, P. (1995). A dominação masculina. Educação \& Realidade (v.20,n.2), pp. 133-84; BADINTER, E. Um é o outro. Rio de Janeiro: Nova Fronteira, 1986. 
problemática do gênero. ${ }^{6}$ Baseando-se na perspectiva de Harry Brod, essa autora aponta que, ao se problematizar a condição masculina, temos a possibilidade de "tomar consciencia de que ser hombre, como todo estado humano, es el resultado, en cualquier tiempo y lugar, de tradiciones, circunstancias e voluntades individuales que esperan para ser examinadas". ${ }^{7}$

Pedro Paulo de Oliveira, no livro que resultou de sua tese de doutorado em sociologia, sem estilizar o fenômeno da(s) masculinidade(s), ou tornar os homens em sujeitos ahistóricos e universais, chama a atenção para as dificuldades e limites de quaisquer tentativas para definir rigidamente esse termo. ${ }^{8}$ Por isso, ele sinaliza a importância de se pensar a(s) masculinidade(s) em suas características históricas como força de arregimentação social, em suas imbricações e lugares simbólicos e o seu poder de orientar a formulação de juízos. Mas, mesmo vendo as definições como horizontes móveis e não como um ponto fixo e rígido de partida, o autor arrisca uma consideração geral, dizendo que a masculinidade é:

[...] um lugar simbólico/imaginário de sentido estruturante nos processos de subjetivação. E complementaria: na qualidade de estrato constitutivo e articulado do socius, apresenta-se como uma significação social, um ideal culturalmente elaborado ou sistema relacional que aponta para uma ordem de comportamentos socialmente sancionados. ${ }^{9}$

No entanto, se partirmos do pressuposto básico de que não é possível definir em termos absolutos quaisquer masculinidades de maneira apriorística e rígida, já que elas são construções históricas e dinâmicas, tanto do ponto de vista científico quanto da vida sócio-cultural, então, é pertinente precisar minimamente os nossos referenciais historiográficos e teórico-metodológicos. Fazêlo vai significar a criação de contornos ou horizontes móveis que nortearão este trabalho dedicado a estudar as masculinidades medievais e suas interrelações com determinadas instituições sóciopolíticas, como o celibato, o casamento, a Igreja e a Monarquia castelhano-leonesas do século XIII.

Do ponto de vista historiográfico, tal como ocorre em outras áreas de conhecimento, estamos presenciando o desenvolvimento de uma corrente historiográfica preocupada com os estudos das

\footnotetext{
6

Cf. PÉROTIN-DUMON, A. Masculinidad. In: . El género en historia, Institute of Latin American Studies, University of London, 2001. Disponivel na Internet via< http://americas.sas.ac.uk/publications/genero/genero_portada.htm>. Acesso em abril de 2013.

7 PÉROTIN-DUMON, Anne. Masculinidad. Op. cit., p. 3.

$8 \quad$ Cf. OLIVEIRA, P.P. Op. cit., p. 13-17.

9 Cf. OLIVEIRA, P. P. Op. cit., p. 13.
} 
chamadas masculinidades medievais. No entanto, eles ainda seguem abordagens gerais, que quase sempre ignoram o medievo ibérico, ou concentram-se em obras monográficas produzidas e divulgadas em inglês sobre algumas regiões da Europa (Itália, França, Germânia, Inglaterra e Império Bizantino). ${ }^{10}$ No âmbito dos Estudos Medievais, a despeito do relativo desenvolvimento dos Estudos de Gênero na e da Medievalística, ${ }^{11}$ ainda há poucos trabalhos que se dedicam a estudar como as diretrizes de gênero constituem e são constituídas pelas práticas e discursos sócio-políticos, econômicos e culturais, sobretudo no que se refere às articulações entre masculinidades e instituições monárquicoeclesiásticas na Península Ibérica medieval. No Brasil, a situação é ainda mais restrita, pois ainda há pouca reflexão crítica do ponto de vista teórico-metodológico e epistemológico sobre as diferenças e semelhanças, mas também as convergências e divergências, estabelecidas entre numerosos ramos ou orientações dos Estudos Feministas, da História das Mulheres, dos Estudos de Gênero e da História das Masculinidades, e suas relações com a Medievalística Ibérica. ${ }^{12}$

Do ponto de vista mais teórico-metodológico, não há consenso sobre o que seria uma História Institucional das Masculinidades, tal como proponho neste trabalho. Portanto, entendo-a aqui como parte distinta, mas inseparável, dos Estudos de Gênero de base pós-estruturalista. Trata-se de um subcampo ou uma subárea móvel dos Gender's Studies, a qual discute se, como e por que as

Cf. KARRAS, R. M. From boys to men: formations of masculinity in the medieval Europa. Philadelphia, Pennsylvania: University of Pennsylvania Press, 2003; UBITEL, L.; LIFSHTZ, F. Gender and Chistianity in medieval Europe; new perspectives. Philadelphia, Pennsylvania: University of Pennsylvania Press, 2008; STONE, R. Morality and masculinity in the Carolingian empire. United Kingdom: Cambridge University Press, 2012; BRADY, S.; ARNOLD, J. (Eds). What is masculinity? Historical dynamics from Antiguity to the Contemporary World. Great Britain: Palgrave Macmillan, 2011; MURRAY, M. The law of the father: patriarchy in the transition from feudalism to capitalism. London, New York: Taylon \& Francis e-Library, 2005; CULLUM, P.H.; LEWIS, K.J. Holi ness and masculinity in the Middle Ages. University of Wales Press: Cardiff, 2004; LEES, C.A. (Ed.)Medieval Masculinities: regarding men in the Middle Ages, Minneapolis: University of Minnesota Press, 1994; HADLEY, D. M.(Ed.) Masculinity in medieval Europe. London, New Yok, Longman: Editor-Dawn Hadley, 1999; KLAPISH-ZUBER, C. Masculino/feminino.In: LE GOFF, J.; SCHMITT, J-C. Dicionário Temático do Ocidente Medieval , v.1. Bauru, SP; Edusc, São Paulo, SP, Imprensa Oficial do Estado, 2002, p. 137-150.

Cf. FRAZÂO. A.C.L.F. Reflexões sobre o uso da categoria gênero os estudos de História Medieval no Brasil (1990-2003). Caderno Espaço Feminino, v.11, n14, jan.jjul., p. 87-107, 2004.

12 Há trabalhos que não pontuam essa relação, mas se dedicam a pensar o fenômeno das masculinidades e as sociedades ibéricas. Cf. RODRIGUES, A.M. Um mundo só de Homens: os capituralares bracarenses e a vivência da masculinidade nos finais da Idade Média, Estudos em homenagem ao professor doutor José Marques, Oporto, v. 1, v. 2, 2006, p. 195-209; ALVARO, B. G. A construção das masculinidades em Castela no século XIII: um estudo comparativo do poema de Mio Cid e da vida de Santo Domingo de Silos. Dissertação de mestrado apresentada ao PPGHC em 2008. Disponível na Internet via < http://teses2.ufri.br/Teses/IFCS M/BrunoGoncalvesAlvaro.pdf>. Acesso em 2013. LOPES, C.R.R. A construção do ideal de masculinidade na sociedade ibero-castelhana do século XIII. Fazendo Gênero 8. Corpo, Violência e Poder. Disponível na Internet via < http://www.fazendogenero.ufsc.br/8/simposios.html>. Acesso em maio de 2013. 
diretrizes de gênero constituem a(s) masculinidade(s) (tanto no singular quanto no plural), ${ }^{13}$ ou são constituídas por ela(s), levando em conta: a) suas arbitrariedades. convencionalidades, já que o gênero é uma construção social e histórica, isto é, ele possui historicidades comparáveis; b) suas (des)continuidades, uma vez que o gênero atua com e sobre corpos sexuados, não sendo um dado puro e isolado da natureza e da biologia, embora suas diretrizes sejam naturalizadas ou "biologizadas" como parte de práticas e discursos binários ; c) suas "relacionalidades" e relatividades, visto que os constructos sociais "homem", "mulher", "homens" e "mulheres", "masculino", "feminino", "masculinidades' e "feminilidades", ou quaisquer outras designações ou configurações "genderizadas", constituem-se mutuamente de forma relacional e relativa; d) suas transversalidades e mobilidades, uma vez que as diretrizes de gênero atravessam e são atravessados por diferentes aspectos da vida social (economia, direito, normas, identidades, etnias, religião, relações de poder, concepções, valores, instituições político-religiosas etc.) e, ao mesmo tempo, possuem, tanto nos discursos quando nas práticas sociais, teores, ritmos ou dinâmicas diversas, podendo ter diferentes pesos na vida social e nas relações de poder.

É a partir dessa perspectiva que analisaremos nossa temática de estudo, isto é, os discursos sobre 0 casamento e o adultério clericais presentes na legislação afonsina.

\section{Casamento e adultério clerical na legislação afonsina}

No final de um dos seus artigos clássicos, a autora Joan Scott havia sugerido que era fundamental sabermos como as instituições sociais incorporam o gênero nos seus pressupostos e nas suas organizações. Seguindo essa agenda, a interseção entre a História Institucional do Direito e os Estudos de Gênero, apesar dos impasses e diferenças, e da multiplicidade de orientações teóricas e metodológicas, pode ser um espaço profícuo na renovação de ambos os campos historiográficos. Nesta parte do trabalho, temos como objetivo central testar os limites e as possibilidades dessa relação, focalizando principalmente a maneira como o casamento e 0 adultério clericais, como instituições sociais, foram (des)articulados às diretrizes de gênero e incluídos como importante ponto de pauta governamental. Mas precisamente, como se trata de um estudo preliminar, concentramos nossa atenção nos complexos processos discursivo-institucionais de d(en)ominação sobre as 
masculinidades clericais representadas, basicamente, em algumas legislações elaboradas no reino de Castela e Leão, do período de governo de Afonso X (1252-1284), século XIII, sobretudo nas chamadas Siete Partidas. ${ }^{14}$

Então, vejamos. A Primeira Partida estabeleceu diversos critérios de diferenciação social sugeridos para orientar os confessores em seu ofício de identificação dos pecados-crimes-erros..$^{15} \mathrm{~A}$ legislação havia admoestado os "penitenciadores" a perguntarem-se "qué persona es aquell que se confiesa" e a levar em conta "otrosi en el estado de su facienda sies clerigo o lego" (Grifo nosso). ${ }^{16}$ Por "estado" entendia-se não somente o lugar da pessoa na hierarquia social, sua situação social, como também o conjunto de expectativas acerca das condições sócio-políticas e jurídicas, dos comportamentos e das maneiras de viver. ${ }^{17}$ Não se tratava de um modo de viver completamente livre: a própria palavra "facienda" reforçava o discurso de que cada membro de um grupo social deveria possuir um conjunto de assuntos a tratar, teria uma fama, uma honraria, mas também um valor, um dever, uma obrigação, enfim, um ethos. Apesar disso não significar imobilismo absoluto, o efeito discursivo desejado era colocar cada um no que se considerava seu devido lugar na hierarquia social.

No Título XXIII, por exemplo, algumas noções gerais de "estado" foram explicitadas a partir de critérios sócio-jurídicos, político-eclesiásticos, étnico-religiosos e "genderizados". Na Lei I, assim define essa categoria: "Status hominum tanto quiere dezir en romance, como el estado, o la condicion, o la manera en que los omes biuen, o estan". As distinções, obviamente, tinham fins jurídicos para definir a distribuição de direitos (garantias e obrigações) a cada um segundo seu pertencimento a um grupo

Para uma análise do contexto de produção e apropriação das Siete Partidas, ver o Capítulo 1 da tese LIMA, M. P. O gênero do adultério... Op. cit. Usamos diversas versões dessa documentação, especialmente as relacionadas à Primeira Partida. Entre as edições consultadas, temos: ALFONSO X. Las Siete Partidas de Don Alfonso X. Barcelona: Impresta de Antonio Bergnes, 1843-1844. Disponível na Internet via < http://fama.us.es/search ${ }^{*}$ spi/c?SEARCH=a+mont.+11+1+15>. Acesso em março de 2013; ARIAS BONET. J.A. Primeira Partida. Manuscrito Add. 20.787 del British Museum. Valladolid: Universidad de Valladolid, 1975; BERNÍ Y CATALÁ, J. Las siete partidas... Edición de Valencia: Imprenta de Benito Monfort, 1767. Edição disponível na Biblioteca Virtual de Pensamiento Político Hispânico Saavedra Fajardo via <http://saavedrafajardo.um.es/WEB/HTML/iniciop.html?Open>. Acesso em março de 2013; BOSSINI, F.R. Primeira Partida (MS.HC.397/573). Hispanic Society of América. Granada: Caja General de Ahorros y Monte de Piedad de Granada, 1984; VANDERFORD, K. H. Setenario. Facultad de Filosofía y Letras de la Universidad de Buenos Aires, Buenos Aires, 1945.

Para uma discussão mais apurada sobre as relações entre pecado, crime e erro na legislação afonsina, ver LIMA, M.P. Do pecado ao gênero da confissão religiosa: algumas reflexões sobre as concepções de pessoa na legislação afonsina, século XIII, Revista Signum, v. 11, p. 236-266, 2010.

Conferir verbete "estado" no Diccionario Medieval Español. Cf. ALONSO, M. Diccionario medieval español. Desde las glosas emilianenses y silenses (s.X) hasta el siglo XV. Tomo I e II, Salamanca: Universidad Pontificia de Salamanca: Imprenta Kadmos, 1986, p. 1093. 
social ou o que era estabelecido pela hierarquia social, já que "mejor pueda ome departir e librar lo que acaesciere en razon de las personas dellos". Na Lei II, o jogo binário de hierarquias complementares foi legitimado da seguinte forma:

La fuera del estado de los omes se departe en muchas maneras, ca otramente es judgada segund derecho la persona del libre, que non la del sieruo; como quier que segund natura non aya departimiento entre ellos. E avn de otra manera son honrados, e judgados los fijos dalgo, que los otros menor guisa; e los Clérigos, que los legos; e los fijos legitimos, que los de ganancia; elos Christianos, que los Moros, nin Judios. Otrosi de mejor condicion es el varon que la muger en muchas cosas, e en muchas maneras, assi como se muestra abiertamente en las leyes de los Títulos deste nuestro libro, que fablan en todas estas razones sobredichas (Grifos nossos). ${ }^{18}$

Esta preocupação em distinguir, separar e hierarquizar era recorrente nos textos normativos afonsinos. Portanto, a filiação legítima, a condição étnico-religiosa, os aspectos jurídicos e sócioeconômicos e morais são os critérios que foram considerados importantes para distribuir a justiça monárquica, estabelecendo quem pode ou não, quem deve ou não, quem tem direito ou não às garantias e obrigações inerentes a sua condição social. Como se pode ver, essa preocupação incluía a distinção básica entre homens e mulheres, e, o que nos interessa mais aqui, entre os clérigos e leigos tanto na relação entre os dois pares, como também internamente. ${ }^{19}$

Enquanto tal, essa preocupação revelou-se uma tarefa complexa e assumida pelos legisladores afonsinos, sobretudo quando consideramos a vida sexual. A continência e, acima de tudo, o celibato clericais foram objetos de uma abordagem constante na Europa e na península Ibérica ao longo da Idade Média. ${ }^{20}$ Ana Arranz Guzmán tem demonstrado em suas pesquisas que os clérigos foram foco da regulação presente nos concílios castelhanos. Segundo a autora, ao lado da gula e da preguiça, a luxúria estava entre os diversos pecados e pecadilhos associados ao clero. ${ }^{21} \mathrm{Em}$ se

Cf. Quarta Partida (Gregório López), Título XXIII, Leis I e II, p. 1120-1122.

19

Cf. SCHMITT, J-C. Clérigos e leigos. In: LE GOFF, J.; SCHMITT, J-C. Dicionário Temático do Ocidente Medieval, v.1, Bauru, SP; Edusc, São Paulo, SP, Imprensa Oficial do Estado, 2002, p. 237-251.

Cf. BEAUDETTE, P. In the world but not of it: Clerical celibacy as a symbol of the medieval church. In: FRASSETTO, M. (ed.). Medieval Purity and Piety. Essays on medieval clerical celibacy and religious reform. New York: London, Garland Publishing, 1998, p. 24-27; GRYSON, R. Les Origines du Célibat Ecclésiastique du premier au septième siècle, Gembloux: Duculot, 1970, p. 197-198; STICKLER, A. M. L'évolution de la discipline du célibat dans l'Eglise en Occident de la fin de l'âge patristique au concile de Trente. In: COPPENS, J.. Sacerdoce et Célibat. Etudes Historiques et Théologiques. Louvain, Ed. Peeters, 1971, p. 373-375.

21 Cf. ARRANZ GUSMÁN, A. Amores desordenados y otros pecadillos del clero. In: In: CARRASCO MANCHADO, A.I.; RÁBADE OBRADÓ, M.P. (Coords). Pecar en la Edad Media. Madrid; Sílex, 2008, p. 259. 
tratando da vida conjugal, mesmo no século XIII, havia clérigos "casados" e "solteiros" convivendo com suas esposas, "barraganas" e concubinas. ${ }^{22}$ Segundo Arranz Guzmán, isso se explicaria em função de tradições peninsulares em que, ao lado de um clero reformador, cioso por regular rigidamente a vida clerical como um todo, havia autoridades eclesiásticas mais tolerantes ou que se encontravam numa situação semelhante convivendo com esposas, "barraganas", concubinas e filhos. ${ }^{23} \mathrm{~A}$ "cumplicidade" e "naturalidade" com que era tratada essa situação foi motivo de variadas tentativas para, se não extinguir, pelo menos restringir a convivência de clérigos com determinadas mulheres.

Os concílios anteriores ao governo de Afonso $X$ dedicaram-se à busca dessa regulamentação. Por exemplo, o Concílio de Valladolid, presidido por Juan de Alegrin, bispo de Sabina, também chamado de Juan de Abbeville, em 1228, seguiu a tendência de aplicar os cânones de Latrão IV (1215), adaptando-os ao contexto castelhano. No decreto De clericis concubinariis, havia a proibição dos clérigos de manterem concubinas e "barraganas", prescrevendo um tratamento assimétrico para os(as) envolvidos(as). ${ }^{24}$ Uma vez denunciados(as) nas Igrejas, os clérigos perderiam o benefício e 0 ofício e as "barraganas publicas" seriam excomungadas. Se, porventura, morressem seus corpos não teriam direito à sepultura cristã, devendo ser enterradas em covas de animais. ${ }^{25}$ Já no decreto $D e$ clericis in maleficio deprehensis, menciona-se, entre outros delitos clericais, o roubo de mulheres, "rapto de mugeres". ${ }^{26}$ O Concílio de Leão, presidido pelo D. Martin Fernandez, bispo de Leão, em $1267,{ }^{27}$ foi uma das poucas assembléias conhecidas e celebradas no reinado de Afonso X. Na segunda

Tratava-se de restrições a determinados grupos de clérigos, sobretudo os ordenados. "clérigos de misa" (preste), aos "de Evangelio"(diacono), "de Epistola"(subdiacono). Cf. TEJADA Y RAMIRO, J. Colección de cânones y todos los concilios de la Iglesia de España y America. Madrid: Imprenta de D. Pedro Montero, 1861, Tomo III.

Cf. Concilio de Valladolid. In: TEJADA Y RAMIRO, J. Colección de cânones y todos los concilios de la Iglesia de España y America. Madrid: Imprenta de D. Pedro Montero, 1861, Tomo III, p.325-326.

Esse esforço para criminalizar a vida sexual do clero ordenado não foi exclusividade do reino de Castela, pois essa tendência estava igualmente presente no Concílio de Lérida, na Calalunha, também presidido por Juan de Abbeville, bispo de Sabina, em 1229. Nesse concílio, o decreto VIII retoma o que foi estabelecido em Valladolid (que seguia Latrão IV), estabelecendo as punições para clérigos que possuiam concubinas. Uma sentença semelhante a de Valladolid recai assimetricamente sobre o clérigo e as concubinas. Nos decretos XXVII e XXVIII, retoma-se as proibições para o comportamente dos clérigos que faziam "rapto de mugeres". Cf. TEJADA Y RAMIRO, J. Colección de cânones... Op.cit., p. 328-339.

Esse concílio também seguiu o que foi designado desde o Concílio de Valladolid, de 1228, que prescrevia a celebração duas vezes por ano de concilios diocesanos. No entanto, dada as especificidades sócio-políticas, econômicas, jurídicas etc. do reino castelhano-leonês, isso não foi possível, pois havia esforços num sentido de articular as instituições monárquico-seculares e eclesiásticas em moldes bem diferentes daqueles previstos pelos reformadores inspirados pela política papal. 
cláusula do decreto De testamentis clericorum, proibiu-se a prática de concessão da penitência a quaisquer clérigos que deixassem seus bens (donacion) a "barraganas publicas" e aos seus "fijos". 28 Ampliando ainda mais as restrições à prática da "barragania", no mesmo concílio, o decreto De concubinis estabeleceu que:

todas las mancebas que publicamente son de los Clerigos, se moiriren, nin sean soterradas, et los Clerigos que las soterrraren, o hi fueren, sena sospensos de oficio et de beneficio; et los Leigos que hi fueren a sciente sean descomungados. Et nin canten hora en la Eglesia, en cuyo cimiterio fur soterrada fasta que sea echada dende. ${ }^{29}$ (Grifos nossos)

Essa legislação conciliar cria punições baseadas em critérios claramente assimétricos e desiguais. Os clérigos são proibidos de possuírem mulheres como esposas, concubinas e "barraganas", em virtude do ethos idealizado correspondente à sua ordo, sendo punidos com a suspensão de um dos elementos que mais caracterizariam sua condição social, isto é, o ofício e benefício eclesiásticos. No caso dos leigos (homens e mulheres?) envolvidos direta ou indiretamente, a punição é a excomunhão. No entanto, para as mulheres de clérigos, além da excomunhão (Concílio de Valladolid), prevê-se uma punição que possui uma espécie de "extensividade" da infãmia que ultrapassaria a vida e alcança o post mortem: ficariam sem sepultura cristã, seriam exumadas no caso de enterradas em cemitério, sobrando somente as covas de animais para seus corpos. Até as atividades litúrgicas seriam suspensas se houvesse uma mulher de clérigos ali enterrada. Sem dúvida, embora a transgressão fosse eminentemente clerical, os efeitos jurídicos prevêem suspensões e interdições nos espaços, em relações comunitárias e sobre corpos sexuados. No jogo de hierarquias, mesclavam-se critérios sócio-jurídicos e morais, mas também "genderizados" de sujeitos considerados ativos e passivos.

A legislação afonsina também incorporou essa tendência, mas o fez ampliando sobremaneira os detalhes regulamentadores. Na Lei XXXVI, além da proibição dos clérigos seculares usarem as roupas, os "habitos de religion", de monges e monjas para "remedar los religiosos", "fazer otros escarnios, e juegos con ellos", proibiu-se que:

28 "Otrosi estableccemos, que los Clerigos des aqui en adelante tovieron borraganas publicas, et fijos ovieren dellas, que lles non puedan hacer donacion, nen les dejar nen en la vida nen en la muerte a tales barraganas nen a tales fijos". Cf. Concílio de Leão In: TEJADA Y RAMIRO, J. Colección de cânones... Op.cit., p. 395. 
los Clerigos, nin los legos, non deuen yr mucho a menudo a los Monasterios de las mugeres Religiosas; fueras ende si lo fiziessen por cosa razonable, e manifiesta, porque lo deuen fazer. E esto mando Santa Eglesia, porque si los omes fuessen mucho a menudo a essos logares atales, podrian nascer sospechas de mala fama, tambien a ellas como a ellos. ${ }^{30}$ (Grifos nossos)

Para o discurso jurídico, a preocupação com a moral do clérigo secular parece ser central. Seria ele mais passível de "imoralidades" e "infâmias" que manchariam sua condição masculino-clerical ao se aproximar de um comportamento masculino-leigo? Para além de uma hierarquia de masculinidades clerical e leiga, haveria um combate a uma hierarquia de mascunilidades entre clérigos seculares e monges? Por um lado, apesar de a norma tratar neste caso dos clérigos seculares e leigos com relativa paridade jurídica (são ordens diferentes com masculinidades aproximadas?), a legislação estava preocupada com a mistura de dignidades seculares e regulares, especialmente ante os sinais externos das suas condições, isto é, as roupas e o comportamento. Por que era considerado ridículo vestir-se de monges? Não sabemos ao certo, mas a imitação jocosa do comportamento religioso monacal por clérigos seculares foi completamente proibida, já que possuía potencialmente uma força disruptiva da ordem social desejada, confundindo os papéis atribuídos aos leigos, aos clérigos regulares e seculares, mas também aos papéis de gênero. Por outro lado, sob o risco de infâmia mútua, ao proibir quaisquer intercâmbios sexuais entre clérigos seculares/leigos e monjas, a norma cria exceções para os casos em que o contato não levantasse suspeita, fosse justificável ou, acima de tudo, fosse manifesto (evidente, claro, não clandestino). ${ }^{31}$

A ordenação clerical, chamada pela documentação de "Ordenes Sacras", "Ordenes Sagradas" ou "Ordenes de Clerezia", era outro critério de distinção que recaía sobre o clero. Havia critérios idealizados para o acesso à ordenação que se fundamentavam quase que inseparavelmente em referências sócio-econômicas, jurídicas, anatômicas, etárias, morais e "genderizadas". Neste caso, segundo a legislação afonsina, não poderiam ser ordenados aqueles homens que cometessem voluntária e injustificadamente um homicídio, ${ }^{32}$ os servos, ${ }^{33}$ os penitentes, ${ }^{34}$ os que possuíssem

30 Cf. Primeira Partida, Título VI, Lei XXXVI, p. 279-380.

31 A "publicidade" das transgressões clericais ainda é um item a ser analisado nas legislações afonsinas, pois ainda não sabemos sobre o jogo de (in)tolerâncias institucionais nos casos em que os delitos não fossem manifestos. Sobre outras distinções entre clérigos e leigos, clérigos regulares e seculares, e monjes e monjas ver LIMA, M.P.; FRAZÃO, A.C.L. Gênero e vida religiosa feminina nas Siete Partidas. Revista Territórios e Fronteira, v. 1, n.2, jul./dez, 2008, p 4668. 
defeitos físicos graves, ${ }^{35}$ os menores de idade, ${ }^{36}$ os que fossem pressionados à ordenação ${ }^{37}$, os filhos de casamento ilegítimo e, claro, as mulheres estavam proibidas de assumir as ordens sacras. ${ }^{38} \mathrm{Em}$ grande medida, essas "personas" eram vistas como submetidas a algum tipo de limite, dependência, incapacidade e subordinação. Além de ser uma "dignidad", o sacramento das ordens era visto também como uma fidalguia, já que seus membros deveriam "ser muy fidalgo, o muy letrado, o de buena vida" 39

Além das distinções entre clérigos e leigos, entre clérigos seculares e regulares, havia outra assimetria ligada ao ordenamento, isto é, havia uma suposta ou efetiva hierarquia desejada e estabelecida entre clérigos ordenados e não ordenados. 0 acesso ao sagrado (aos sacramentos, em especial, à eucaristia) e a administração do ofício eclesiástico foram as justificativas ventiladas aqui e ali pelas leis afonsinas para que os clérigos mantivessem o "complimiento de buenas costumbres", a "limpia vida" e para que se guardassem "de los yerros que menguan la buena fama", especialmente "vna de las cosas que mas abilta la honestad de los Clerigos, [que] es auer grand criança con las mugeres". 40 Por "criança ["crianza"] con las mugeres" entendia-se um amplo espectro de ações buena e santa. Ca como quier que Santa Maria Madre de Jesu Cristo fue mejor, e mas alta que todos los Apostoles, non le quiso dar poder de absoluer, mas diolo a ellos, porque eran varones". Cf. Primeira Partida (Gregório Lopez), Título IX, Ley IV, p. 477- 479. Cf. Também Primeria Partida (Gregório Lopez), Título IV, Lei XXVI, p. 371. Para uma análise mais aprofundada e contextualizada da exclusão das mulheres do poder político-religioso, eclesiástico e pastoral ver LIMA, M.P. Ciência política, medievalismo e estudos de gênero: a propósito das relações de poder no reino castelhano-leonês, séc. XIII. Atas da VII Semana de Estudos Medievais do Programa de Estudos Medievais da UFRJ, 28 a 30 de novembro de 2007. Rio de Janeiro: março de 2008, p. 116-123.

Cf. Primeira Partida (Gregório Lopez), Título VI, Leis Lei XXVII, p. 372.

"Honestas en latín, quiere dezir en romance, tanto como complimiento de buenas costumbres, para fazer ome limpia vida, segun el estado en que es, e esto conuiene a los Clerigos, mas que a otros; ca ellos han de fazer tan santas, e tan bonrradas cosas, como de consagrar el Cuerpo de nuestro Señor Jesu Christo, e dar los Sacramentos, e administrar el Altar, e seruir la Eglesia, mucho les conuiene de ser limpios e honestos, e de se guardar de los yerros que menguan la buena fama: e vna de las cosas que mas abilta la honestad de los Clerigos, es auer grand criança con las mugeres. E por los guardar deste yerro, tono por bien Santa Eglesia de mostrar, quales mugeres pudiessen con ellos morar sin mal estanca, e son estas: madre, abuela, hermana, e tya hermana de padre , o de madre; sobrina fija de Hermano, o de hermana; su fija misma que ouiesse de bendiciones, ante que rescibiesse Orden Sagrada; e su nuera muger velada de su fijo legitimo, o otra que fuesse su parienta en el segundo grado, assi como prima cormana. E estas pueden morar con ellos por esta razon; porque la naturaleza del parentesco es tan cercana entre ellos, que faze a los 
ligadas à nutrição, educação e cuidados com a parentela feminina, mas também, supomos, de eventuais intercursos sexuais entre clérigos ordenados e mulheres da rede parental. Na Lei XXXVII, não era fortuito que um conjunto de figuras femininas fosse vedado ao convívio doméstico com os clérigos ordenados, excetuando-se as parentas tais como as mães, avós, irmãs, tias paternas e maternas, sobrinhas cognatas, filhas de casamento legítimo antes da ordenação, as noras de filhos legítimos, as parentas de segundo grau e, por fim, as primas (filhas dos(as) irmãos(ãs) do pai e da mãe).

O Primeiro Concílio de Latrão (1123), retomando a tradição conciliar nicena, já havia proibido a convivência de sacerdotes, diáconos e subdiáconos com concubinas, esposas e a coabitação "em razão das necessidades da vida" com mulheres que não fossem a mãe, a irmã, a tia paterna ou materna e "outras que não dêem lugar a uma suspeita justificada". ${ }^{41}$ As leis afonsinas retomam, ampliam e especificam essas restrições. Tal como Latrão I, a legislação afonsina ampliaram suas concessões em virtude do suposto limite que o tabu do incesto ofereceria para debelar quaisquer possibilidades de intercurso sexual entre clérigos e mulheres suspeitas.

Mas parece que o parentesco não foi um critério suficiente em si mesmo para sustentar as restrições de convivência social entre figuras masculinas e femininas. A Lei XXXVIII complementa a norma anterior para os casos de relações "incestuosas" consideradas perigosas, visto que seriam motivadas pelo "engaño" e pelo "decebimiento del diablo". Nesta lei, a restrição da convivência doméstica sob suspeita só seria permitida mais elasticamente nos casos em que as parentas fossem pobres e velhas. Mas, neste caso, o critério sócio-econômico também foi atravessado pelas questões etárias e de gênero. A casuística jurídica afonsina previa algumas situações: a) se a parenta fosse pobre e dependesse do clérigo para sobreviver deveria morar longe de sua casa de modo que pudesse receber 0 sustento dele sem que isso gerasse desconfiança; b) se os clérigos das Ordens Maiores (subdiácono, diácono, presbítero, bispo, arcebispo, patriarca etc) ${ }^{42}$ tivessem sido ordenados depois do

omes que non deuen sospechar mal. E como quier que tales parientas, como estas sobredichas, pueden tener consigo, non deuen ellas tener consigo otras mugeres, de quien pudiessen sospechar, que fazen yierro con ellas los Clerigos, e si las touieren, non deuen morar con ellos; e sobre esto dixo Sant Agustín vn proverbio, que acuerda con esta razon, que todas las que morauan con sus hermanas, non eran sus hermanas: e porende deue ome a las veces dexar de fazer algunas cosas razonables, si entiende que son atales, que podria caer por ellas en cosas desaguisadas, 0 en mala sospecha".Cf. Primeira Partida (Gregório Lopez), Título VI, Lei XXXVII, p. 380-381.

A hierarquia eclesiástica foi representada pelas Partidas como uma "mejoria", uma cadeia de mando e obediência ideal, de amor dos menores em relação aos maiores, uma cadeia de serviço baseada no "direito" (privilégio) de cada um. São, portanto, "grados" que pertencem a "Santa Eglesia". Seguindo o vocabulário dos textos afonsinos, as ordens menores são: "corona" ("psalmistas"), "hostiario", "lector", "exorcista", "acolito". As ordens maiores são: subdiácono 
casamento legítimo com o consentimento da mulher, eles teriam que proceder de duas outras maneiras.

Nos casos em que suas esposas fossem já idosas previa-se que elas prometessem a castidade e morassem afastadas dele. Nas situações em que as esposas fossem ainda jovens, a situação prescrita era mais rígida e diferente: elas deveriam ser obrigadas a entrarem num mosteiro. ${ }^{43}$ Com essa distinção no interior do universo feminino, a norma afonsina acreditava atacar um dos cernes da vida do clero "casado", ou seja, as suas obrigações familiares, isto é, a prática sexual, a convivência conjugal, pós-conjugal, o sustento e a filiação. É difícil não ver nessa assimetria de subordinação dos corpos femininos uma forma de controle também sobre os corpos masculinos. Obviamente, temos que encarar o discurso afonsino como uma estratégia de manutenção do celibato clerical, porque as leis tinham uma expectativa estereotipada quanto ao suposto perigo que a sexualidade feminina provocava, um perigo maior ou menor conforme a idade. Talvez, muito mais significativo do que isso seja a própria concepção de que o corpo feminino era uma relativa continuidade ou extensão do masculino. A reflexão da historiadora Dyan Elliott, quando discute o tema dos votos simples ou solenes de mulheres e homens que decidiam substituir a vida conjugal por algum tipo de "spiritual marriage", é valida para nossa análise dos textos afonsinos. Para essa autora, "the women was placed in an ambiguous position, with regard to both her own body and her husband. Her position was unique". ${ }^{44} \mathrm{O}$ ordenamento clerical das ordens maiores significava o afastamento direta ou indiretamente variável do feminino e de seus corpos.

("epistoleros"), diácono ("evangelisteros"), "preste" ("missacantano") e bispo ("obispo"). Cf. Primeira Partida (Gregório Lopez), Título VI, Prólogo, p. 346-347.

"Morar pueden con los Clerigos por razon de parentesco, aquellas mugeres que son dichas en la ley ante desta. Pero con todo eso guardar se deuen ellos, que non ayan con ellas gran privança, e gran fazimiento: ca por engaño, 0 por decebimiento del diablo, algunos Clerigos cayeron ya en tal yerro, e en tal pecado con sus parientas, e podrian caer con las otras que morassen con ellas. E por ende defiende Santa Eglesia, que si el Clerigo fuer tal, o la parienta que mora con el, de quien aya sospecha, que podria caer en tal pecado, que non moren en vno. Pero si la parienta fuer tan pobre, que non pueda escusar su bien fazer, deue morar lueñe de la casa del Clerigo, e alli le faga el bien que pudiere, e de las otras parientas non deue tener el Clerigo en su casa, si sospechassen contra el, que fazia yerro con ellas. Esso mismo deue guardar de las otras mugeres, con quien note ouiesse parentesco; e quando tal sospecha fuer fallada contra algun Clerigo, deuele amonestar su Obispo, que se parta della: e si non quisiere, deuele toller el Beneficio que ouier de la Eglesia, e vedarle que non diga Horas en ella. Otrosi manda Santa Eglesia, quel que fuere ordenado de Epistola, o dende arriba con otorgamiento de su muger, que ouiesse antes auido de bendiciones, que si ella fuere muy vieja, que deue prometer castidad, e morar apartadamente e non con el, e si fuere moça, deue entrar en Orden de Religion; assi como ella faria, quando el entrasse en Orden con otorgamiento della". Cf. Primeira Partida (Gregório Lopez), Título VI, Lei XXXVIII, p. 381-382.

44 Cf. ELLIOTT, D. Conjugal Dept and Vows of Chastity. In: wedlock. Priceton, New Jersey: Priceton University Press, 1993, p. 151-152. Spiritual Marriage: sexual abstinence in medieval 
Os clérigos das Ordens Menores (ostiário, leitor, exorcista e acólito), que não receberam as ordens sacras, tinham pemissão para casarem legitimamente com quem desejassem, mas deviam fazê-lo seguindo restrições semelhantes ao estabelecido para os homens e mulheres leigos. A Lei XVI, Título II, da Primeira Partida, contrastando as ordens maiores com as menores, assim se refere ao "adultério", caracterizando-o como "fornicação carnal" diferente da "fornicação espiritual". Segue-se uma pauta semelhante às prescrições sobre o casamento monogâmico de base romano-canônica leiga, incluindo aqui a possibilidade de dissolução justificada dos laços conjugais em razão do adultério.

Nueue grados de Orden ha en Santa Eglesia, segun dize en el Titulo de los Clerigos. E destos los tres mayores embargan el casamiento. Onde qual Clerigo quier que fuesse ordenado de alguno de los tres mayores Ordenes, assi como de Subdiacono , o de Diacono, o de Preste, non deue casar; e otrosi, si casare, deue ser desfecho el casamiento. E esta es la octava cosa que embarga el casamiento, que se non faga; e si fuere fecho, deuenle desfazer. La nouena cosa es quando alguno es ligado, por mal fecho que le fizieron, de manera, que non puede yazer con muger. Pero esto se entiende, si auia ya el embargo, ante que se desposasse con ella por palabras de presente. Mas si despues que el casamiento fuesse fecho, viniesse este embargo, 0 otro, de enfermedad, o de qualquier manera, non se desfaria el matrimonio por el; fueras ende, si fiziesse fornicio spiritual, o corporal. E spiritual seria, si se tornasse hereje, 0 de otra Ley [judeus e mouros]; e corporal si yoguiesse con otra muger, si non con la suya, o ella con otro ome, si non con su marido. ${ }^{45}$ (Grifos nossos)

Mas os textos afonsinos fizeram outras distinções entre os clérigos que tinham permissão para casar. Neste caso, a Lei XXXIX contrasta as diferenças entre os clérigos orientais e ocidentais. Para a lei, havia acordos e desacordos entre essas duas tradições. O quarto grau de parentesco seria supostamente uma referência exigida para que o casamento fosse considerado legítimo nos dois espaços geográficos. Em contraste, enquanto os "Clérigos de Oriente", casados ou não, podiam receber as ordens sagradas sem prometer manter a continência e sem desfazer o casamento, os "Clérigos de Occidente" não poderiam fazê-lo. ${ }^{46}$ Nessa mesma lógica de contrastes entre oriente e ocidente, a Lei XL prevê um série de implicações para a vida das mulheres de clérigos ordenados.

$46 \quad$ "Pero algunas cosas y a en que acuerdan, e otras en que desacuerdan en razon de casamientos; e las en que acuerdan son estas: que tambien los vnos como los otros pueden casar, auiendo quatro grados: e otrosi que non pueden casar, desque ouieron Orden Sagrada; e si casaren, que non vale el casamiento. E las en que se desacordaron son estas: que los Clerigos de Oriente, quier sean casados, quier non, pueden rescebir Ordenes Sacras, non prometiendo de guardar castidad; mas los de Occidente non pueden esto fazer, amenos de lo prometer. E otrosi desacuerdan en otra cosa: ca los de Oriente, seyendo casados con sus mugeres, pueden rescebir Ordenes Sagradas, non se departiendo el casamiento porende, antes deuen biuir en vno, tambien como fazian de primero; e los de 
Para o ocidente, a lei ordena que as mulheres que consentissem com a ordenação de seus maridos deveriam "prometer de biuir en castidad, e de non morar con ellos; e otrosí, desque ouieren sus maridos muertos, que non se puedan despues casar, e si casaren, non vale el casamiento". A lei dispõe as razões: primeiro, "por la obligacion de la castidad, que ha en si la Orden"; segundo, "porque la Eglesia defendió, que si los Clerigos que son de Ordenes Sagradas, ouiessen mugeres, e casassen ellas despues de su muerte dellos, que non valiesse el casamiento". Para o oriente, as razões seriam mais laxistas, mas também possuíam restrições duais: "La vna, que non pueden casar despues quellos son muertos, quier contradigan, o non, quando se quisieren ordenar. La otra, que non se deue ninguna dellas ayuntar con sus maridos, en aquella semana quel ouiere a dezir las Horas". Estas implicações jurídicas só mudariam de rumo se as figuras femininas não tivessem consciência ou não fizessem a concessão ao ordenamento do marido. Neste caso, as mulheres não seriam prejudicadas, isto é, "non les tiene daño a ellas", podendo demandar pela convivência conjugal e exigir o cumprimento do débito conjugal, isto é, "faziendo aquellas cosas, que marido deue facer con muger". As obrigações matrimoniais teriam precedência. No entanto, os clérigos ordenados perderiam o direito de demandar pelo sexo da esposa uma vez que "son tenudos de guardar castidad, por la Orden que rescibieron". ${ }^{47}$

Occidente non lo pueden fazer, ca despues que resciben tales Ordenes non pueden beuir en vno". Cf. Primeira Partida (Gregório Lopez), Título VI, Lei XXXIX, p. 382-383.

"Estoruo viene a las mugeres a las vegadas en sus casamientos, por las Ordenes que resciben sus maridos: ca si los Clerigos de Occidente, e que dize en esta otra ley, se ordenan sabiendolo sus mugeres, e lo consienten, que lo non contradixessen, mas callassen, vieneles desto dos embargos: el vno, que de allí adelante son tenudas de prometer de biuir en castidad, e de non morar con ellos; e otrosí, desque ouieren sus maridos muertos, que non se puedan despues casar, e si casaren, non vale el casamiento. E esto por dos razones. La vna, por la obligacion de la castidad, que ha en si la Orden, segun de suso es dicho. La otra, porque la Eglesia defendió, que si los Clerigos que son de Ordenes Sagradas, ouiessen mugeres, e casassen ellas despues de su muerte dellos, que non valiesse el casamiento. Otrosi embargan a las mugeres de los Clerigos do Oriente en dos maneras las Ordenes que resciben sus maridos. La vna, que non pueden casar despues quellos son muertos, quier contradigan, o non, quando se quisieren ordenar. La otra, que non se deue ninguna dellas ayuntar con sus maridos, en aquella semana quel ouiere a dezir las Horas. E como quier que de suso dize en esta ley, que las Ordenes Sagradas que reciben los Clerigos de Occidente, que estoruan a sus mugeres en los casamientos; pero si quando ellas saben que sus maridos se quieren ordenar, lo contradizen, o ellos se ordenan sin su voluntad, o sin su sabiduria, en qualquier destas maneras, non les tiene daño a ellas; ca bien los pueden demandar que moren en vno, compliendo, e faziendo aquellas cosas, que marido deue facer con muger; mas ellos non pueden esto demandar a ellas, porque son tenudos de guardar castidad, por la Orden que rescibieron. Otrosi quando algun Clerigo ouiesse rescebido Orden Sagrada, e su muger lo demandasse, e el pusiesse defension ante si, quella fiziera adulterio, si gelo prouare, non es tenudo de dexar la Orden, e biuir con ella". Cf. Primeira Partida (Gregório Lopez), Título VI, Lei XL, p. 383-384. Outras leis prevêem outros tipos de situações: "Casandose algun Clerigo que ouiesse Orden Sagrada, non debe fincar sin pena; ca deuenlo de vedar de oficio, e toller el Beneficio que uiere de la Eglesia, per sentencia de excomulgamiento, fasta que la dexe, e falga penitencia de aquel yerro. E la muger si fuere vassalla de la Eglesia, e sopiere que es Clerigo aquel con quien casa, deuela meter el Obispo en seruidumbre de la Eglesia; e si el por si non lo pudiere fazer, deuelo dezir al Rey, o al Señor de aquella tierra que lo ayude a fazerlo. E si fuere sierua, deuela vender, e el precio della della deue ser metido en pro de la Eglesia, donde es el Clerigo que lo fizo. E los fijos que nascieren destas mugeres, deuen ser metidos en seruidumbre de la Eglesia, e non deuen heredar 
Em parte, esse conjunto de leis sobre os clérigos ocidentais e orientais é uma apropriação ampliada de tradições romano-canônicas presentes nas prescrições de Latrão IV (1215). Um dos seus cânones recomendava que "os clérigos que, conforme o costume de sua região, e que não tivessem renunciado ao matrimônio, se caem na impureza serão castigados mais severamente ainda, posto que tinham permissão para viver em legítimo matrimônio".48 No que tange ao discurso afonsino, mesmo considerando o papel jurídico decisivo do consentimento e vontade femininos nos votos dos maridos, aqui, nas leis Lei XXXIX e Lei XL, se retoma o mesmo fundamento discursivo de que o corpo feminino era visto parcialmente como extensão do corpo masculino. Do ponto de vista da lei, embora tanto os clérigos quanto as suas esposas ilegítimas devessem perder o status social, submetendo-se a determinadas consequêencias jurídicas, ambos deveriam perder tal status de forma diferente em termos de gênero. Esse princípio cultural era tão significativo que a imposição da castidade permanente ou momentânea e 0 impedimento de segundas núpcias das esposas dos clérigos casados antes da ordenação permaneceriam até mesmo após a morte do cônjuge masculino.

A "barragania" era tolerada aos homens leigos, mas completamente proibida para os clérigos das ordens maiores. ${ }^{49}$ Além das restrições sobre a convivência com suas esposas depois da ordenação, era proibido que clérigos mantivessem a convivência sócio-conjugal e o exercício do pecado-crime-erro de luxúria com concubinas manifestas 50 e "barraganas" encobertas. ${ }^{51}$ Só para se ter

de los bienes de sus padres. Otrosi manda Santa Eglesia, quel Clerigo que rescibiere Ordenes Sagradas, con otorgamiento de su muger de bendicion, e prometiendo ella de guardar castidad, segund dize en la ley ante desta, que si despues tornare a ella, que deue perder el Beneficio que ouiere, e ser vedado, que non vse de la Orden que auia". Cf. Primeira Partida(Gregório Lopez), Título VI, , Lei XLI, p. 384-385.

Em se tratando do universo clerical, havia uma tendência para negar o envolvimento de clérigos ordenados com esposas, concubinas e "barraganas". No caso da "barraganía", tratava-se de um vínculo amplamente tolerado para os(as) leigos(a) pela legislação afonsina. Focadas na perspectiva masculina, ela situava-se num lugar móvel e intermediário entre 0 casamento legítimo e o concubinato simples. Esse estado intermediário fez com que a "barragania" compartilhasse das duas condições. Nas Partidas, ela foi negada a "todo ome que non fuesse embargado de Orden o de casamiento" e aos "adelantados", mas bastante tolerada para os chamados "illustres personas" ou "personas honrradas" (portadores de dignidades tais como reis e condes). Apesar disso, para o discurso afonsino, mesmo para essas autoridades seculares, seria proibida a "barragania" com virgens (consagradas?), viúvas (consagradas?), parentes até o quarto grau de parentesco, com mulheres casadas, maior de doze anos, as servas, as "aforrada(s) (auforriadas), "juglaressa(s)" (juglaresas), "tauernera(s)"(taverneiras), "regatera(s)"(regateiras), "alcahueta(s)" e otras mulheres "viles". Além disso, seguindo alguns preceitos sistematizados em Latrão IV, a leis que regulam sobre a "barragania" pautam-se numa configuração jurídica muito semelhante ao que era prescrito oficialmente ao casamento legítimo em seu caráter moralmente monogâmico e reprodutivo. Cf. Quarta Partida (Gregório Lopez), Título XIV, Leis I, II e III, p. 1051-1056. 
uma ideia, a presença suposta ou efetiva das mulheres de clérigos ordenados era motivo suficiente para alterar as regras de confissão religiosa. Os juristas afonsinos concederam a possibilidade de a confissão ocorrer fora da paróquia sem qualquer licença especial nos casos de mulheres em que 0 confessor "hobiesse fecho pecado" ou "lo toviese en corazon de lo facer". Essa mesma concessão foi estendida ao homem que tivesse pecado "con la barragana daquel clerigo":

Pero cosas podrian hi acaescer por que lo farian con derecho: et esto serie si aquella persona que se quisiese ir manifestar fuesse muger con que el penitenciador hobiese fecho pecado, o lo toviese en corazon de lo facer, o si fuese varon quel hobiese acaesido de pecar con la barragana del clerigo $(. ..) .^{52}$

Direta ou indiretamente ligada à vida clerical, é justamente nesse processo de personalização dos pecados sexuais que o adultério emerge como mais um critério de distinção. Ele foi associado a uma força disruptiva no processo de ordenação clerical pelo direito afonsino: "Otrosi quando algun Clerigo ouiesse rescebido Orden Sagrada, e su muger lo demandasse, e el pusiesse defension ante si, quella fiziera adulterio, si gelo prouare, non es tenudo de dexar la Orden, e biuir con ella". (Grifo nosso) Aqui se trata da perspectiva teleológica da sexualidade conjugal, isto é, a exposição do direito feminino à convivência e ao débito conjugal, semelhante ao que era válido para os leigos. $O$ adultério feminino foi interpretado como justificativa legítima para subtrair o direito das esposas pela manutenção

vedar de oficio e de Beneficio, si el pecado fuer por juyzio conoscido, que den contra alguno dellos sobre tal razon; 0 porque lo el conosciesse en pleyto; o si el yerro fuesse tan conoscido, que se non pudiesse encobrir, como si la touiesse manifiestamente en su casa, e ouiesse algun fijo della; e del Clerigo que en tal pecado biuiere, non deuen sus parrochianos oyr las Horas del, nin rescebir los Sacramentos de Santa Eglesia del. Pero aquel que fallaren que la tiene conoscidamente, assi como dicho es, deuele amonestar su Perlado, que se parta della, ante que le tuelga el Beneficio, e si por esto non se quiere partir della, nin emendar, deuengelo toller fasta un cierto tiempo; e si en aquesse tiempo non se quisiere partir della, deuengelo toller para siempre: e la muger que desta manera biuiere con el Clerigo, deue ser encerrada en un Monesterio, que falta y penitencia por toda su vida". Cf. Primeira Partida (Gregório Lopez), Título VI, Lei XLIII, p. 386.

"Enfamado seyendo algun Clerigo que tiene barragana encubiertamente, maguer que non le acusasse ninguno dello, a tal como este, desque su Obispo lo supiere, deue mandar, que se salue, que non es en aquella culpa que sospechan del. E esta salua ha de fazer, segund que su Perlado fallare por derecho. E si non quisiere saluarse, o non pudiere, deuele toller el Beneficio, e vedarle que non diga Horas en la Eglesia. Pero este atal non deuen sus perrochanos dexar de oyr las Horas del, nin de recebir los Sacramentos, mientra que su Perlado le sufriere que diga las Horas, e sirua la Eglesia. E non tan solamente defendió Santa Eglesia a los Clerigos, de morar con las barraganas, mas avn, que no fablen con ellas apartadamente. E si por ventura lo ouieren a fazer por alguna derecha razon, deuen auer consigo algunos compañeros, porque non puedan sospechar contra ellos, los que los vieren, que lo fazen a mala parte". Cf. Primeira Partida (Gregório Lopez), Título VI, Lei XLIV, p. 387.

Cf. Primeira Partida (Real Academia), Título IV, Lei LXXVIII, p. 140. Na versão de Gregório Lopez e no Setenario contêm as mesmas concessões com poucas alterações. Cf. Primeira Partida (Gregório Lopez), Título IV, Lei XXXIII, p. 207-208. O Setenario registra a seguinte expressão: "touyesse uoluntad de lo ffazer", já a versão de Gregório Lopez diz "e se trabajase aun de lo facer". Cf. Setenario, Lei Cl, p. 214. 
e precedência da vida conjugal ante as ordens sacras. A Lei XLII complementa as restrições de convivência entre os clérigos ordenados e suas antigas mulheres legítimas, apontando a necessidade de os bispos separarem o casal e evitarem que eles(as) comam e bebam juntos, morem na mesma casa, mas também incentivando-os preferentemente que eles convivessem com homens e mulheres insuspeitos(as), isto é, "omes buenos, e mugeres buenas", com exceção do espaço da Igreja ou "otro logar publico, donde non puedan auer sospecha mala contra ellos". 53

A mesma Lei XLII foi mais contundente na prescrição de normas para limitar a prática sexual ilícita com mulheres casadas. Neste caso, se "algun Clerigo fiziesse adulterio con muger que ouiesse marido, deuelo echar su Obispo del Obispado para siempre, o fazerlo encerrar en algun Monesterio, a do faga penitencia por toda su vida, e esto es, porque el pecado es muy grande, e disfamado"(Grifo nosso). ${ }^{54}$ Tal como ocorria com os leigos, o direito afonsino reconheceu a possibilidade de os clérigos serem sujeitos do adultério nos casos em que a relação sexual tenha se dado com uma mulher casada, isto é, "con muger que ouiesse marido". Assim, o pecado clerical "es muy grande, e disfamado", porque tinha se dado com figuras femininas que deveriam manter os laços de fidelidade conjugal com seus maridos e não o fizeram. No entanto, dada a condição de clérigo ordenado, o adultério teve implicações específicas, já que ele deveria se subordinar ao bispo, fazer penitência e ser encerrado num mosteiro. O adultério clerical com mulheres casadas previa a imposição de uma subordinação e enclausuramento semelhantes àqueles dados às mulheres casadas depois da ordenação de seu marido. ${ }^{55}$ Tratar-se-ia de uma espécie de "feminilização" ou "desmasculinização" dos clérigos adúlteros ao receberem punições semelhantes às mulheres de clérigos ordenados? Ainda não o sabemos.

Em uma versão da Primeira Partida (Add 20787 do British Museum, identificado como B. R. 3), algo semelhante é dito para os clérigos seculares. De forma mais laxista, destacaram-se a possibilidade de manutenção dos direitos eclesiásticos (ordenação, ofício e benefício), por meio da

53 Cf. Primeira Partida (Gregório Lopez), Título VI, , Lei XLII, p. 385.

$54 \quad$ "Departiendo el Obispo a los Clerigos, que dize en la ley ante desta, de las mugeres que tomaron a bendicion, porque se ayuntaron a ellas contra defendimiento de Santa Eglesia, develes fazer jurar, que de alli adelante non se ayunten con ellas nin coman, nin beuan, nin esten so vn tejado; fueras ende, en la Eglesia, o en otro logar publico, donde non puedan auer sospecha mala contra ellos. $E$ avn alli que non fable con ella apartadamente, si non fuere ante omes buenos, e mugeres buenas. E estonce por alguna cosa conuenible, e buena, por que lo aya de fazer. E si algun Clerigo fiziesse adulterio con muger que ouiesse marido, deuelo echar su Obispo del Obispado para siempre, o fazerlo encerrar en algun Monesterio, a do faga penitencia por toda su vida, e esto es, porque el pecado es muy grande, e disfamado". Cf. Primeira Partida (Gregório Lopez), Título VI, , Lei XLII, p. 385.

55 "[...] e la muger que desta manera biuiere con el Clerigo, deue ser encerrada en un Monesterio, que falta y penitencia por toda su vida". Cf. Primeira Partida (Gregório Lopez), Título VI, Lei XLIII, p. 386. 
penitência e de acordo com a gravidade do pecado cometido, o tipo de relacionamento e as condições sócio-jurídicas das figuras femininas:

[...] deben le mandar, si fuere preste que non cante misa, et si fuere diacono, que non cante evangelio, et si subdiacono, que non diga epistola, mas que use cada uno dellos de las otras ordenes que hubiere fasta que su obispo perdone et despense con ellos. Mas si fuere encobierto el pecado desque hubiere fecho penitencia del, non le embarga para poder esleer nin ordenar, nil poden por ende toller el logar nin las ordenes que hubiere; et aun mas dixieron, que non deben a ningun clerigo desponer por pecado que faga con muger soltera, maguer sea manifiesto, fueras ende si hobiesen amonestado et non se quisiese castigar; mas si algun clerigo se alabare de alguna que fuese ya casada que la hobo virgen, o que iogo con ella despues que obo mandado, debenle vedar por ende de oficio et de beneficio. ${ }^{56}$ (Grifos nossos)

Embora o enclausuramento não tenha sido previsto neste último caso, não se deixou de criar restrições ao acesso às mulheres, variando a gravidade das conseqüências jurídicas de acordo com a condição de casadas ou solteiras das mulheres, virgens ou não. Trata-se de um jogo de identidades atribuídas às figuras femininas que, fraturadas e essencializadas, implicariam em conseqüências jurídicas diferentes para os clérigos. Além disso, o adultério clerical foi confundido também com a simples fornicação quando foram considerados pecados "medianos", mas não era considerada uma transgressão irreconciliável. ${ }^{57} \mathrm{O}$ adultério foi incluído entre os delitos cometidos por clérigos que potencialmente fossem "dispensados", isto é, permitidos pelos seus "prelados maiores" para permanecerem nos seus respectivos ofícios nos casos de pecados sexuais, desde que cumprissem penitência: "E pueden avn dispensar, que finquen en sus Ordenes los Clerigos que fazen adulterio, 0 otros pecados menores, o otros mayores, despues que ouieren fecho penitencia"(Grifo nosso). ${ }^{58}$ Dada a mistura de significados entre as palavras "adulterio" e "fornicação", é provável que essa menção anterior estivesse associada amplamente aos clérigos concubinários ou, pelo contrário, aos que cometessem adultério com mulheres casadas, cuja transgressão estaria correlacionada à desonra transmitida pelo clérigo ao marido através dos corpos femininos. Mais uma vez, os corpos femininos

Cf. nota "m" da Primeria Partida (Gregório Lopez), Título V, Lei 33, p. 309.

"E los pecados medianos dizen que son estos, assi como adulterio, fornicio, falso testimonio, robo, furto, soberuia, auaricia, que se entiende por escasseza, saña de luengo tiempo, sacrilejo, perjuro, beodez cotidiana , engaño en dicho o en fecho, de que viene mal a outro". Cf. Primeira Partida (Gregório Lopez), Título V, Lei XXXIII, p. 309-310. 
faziam parte de uma concepção de pessoa jurídica associada a um sujeito passivo e transmissor de honra e desonra entre sujeitos ativos (clérigo adúltero e marido).

Apesar da regra geral e contundente de que os clérigos das ordens maiores não pudessem ter esposas e nem cometer adultério, o direito afonsino prevê uma relativa flexibilização da imposição da norma nos casos de dispensa episcopal. Os bispos poderiam permitir a manutenção do ofício eclesiástico por clérigos ordenados que se casassem com mulheres virgens, ou seja, aquelas em que não se corria o risco de provocar imediatamente alguma desonra a um homem casado: "E han poder de dispensar que vse de su oficio con el Clerigo que fuesse ordenado de mayores Ordenes, si casasse con muger virgen: e esto despues que ouiesse fecho penitencia" (Grifo nosso). Relacionando-se com mulheres virgens, os clérigos ordenados poderiam manter seu oficio mediante penitência. Sem dúvida, as conseqüências previstas eram menores do que se a prática sexual tivesse ocorrido com mulheres casadas. Neste caso, o que estava em jogo era o grau de ofensa que a atividade sexual provocaria aos sujeitos e corpos masculinos dos maridos traídos e não aos corpos femininos propriamente ditos.

Mesmo considerando as matizações acima expostas (o acesso às mulheres virgens ou casadas, por exemplo), é plausível que a imposição do enclausuramento e/ou da penitência, para os clérigos que cometessem adultério com mulheres, fosse uma estratégia de prevenção para que eles não voltassem a cometer esse pecado. Mas, ao lado disso, era também uma clara exigência de retorno ao que se esperava de uma "masculinidade ascética" desejada para o clero. ${ }^{59}$

Como o casamento legítimo foi idealmente pensado como um contrastante critério moral e jurídico para diversas atividades clericais, ele não deixou de ser um fator fundamental para a ordenação e eleição dos bispos. Nesse caso, as Partidas listaram os aspectos considerados fundamentais para o acesso dos clérigos ao grau episcopal. Como vigários de Deus na terra, postos por Ele no lugar dos apóstolos com o poder de ligar e desligar na terra e no céu, os bispos ("perlados mayores") foram considerados "adelantados", 'guardadores", ou chamados de "padres spiritualmente" e, por isso, suas "personas" deveriam cumprir determinadas exigências estilizadas ou idealizadas para postular o ofício eclesiástico. Dada sua considerada superioridade na ordem clerical, "la persona del elegido" não deveria ser consagrada à dignidade episcopal sem a unção, ${ }^{60}$ não poderia ser "ome que

\footnotetext{
59 Esse termo foi cunhado por LEYSER, C. Masculinity in Flux: Nocturnal Emission and the Limits of Celibacy in the Early Middle Ages. In: HADLEY, D. M. Masculinity in Medieval Europe, London/New York, Longman, 1999, p. 110-112. 
non sea letrado", ${ }^{61}$ deveria ter no mínimo trinta anos, ${ }^{62}$ ser batizado, não ter sofrido excomunhão ou interdito, não poderia ser cismático, herege, infiel convertido, leigo e clérigo que não tivesse ao menos o grau da "Orden de Epistola (subdiácono)" etc.63

Dentro disso, a moral sexual foi igualmente considerada um critério fundamental para o acesso à ordenação episcopal. Neste caso, os postulantes não poderiam ser filhos de casamentos clandestinos, isto é, não poderiam ser "fijo de muger velada"64 ou deveriam ser "nascidos de legitimo matrimônio". 65 Seguindo a trilogia classificatória entre pecados grandes, medianos e pequenos, ${ }^{66}$ as Partidas ainda estabeleciam um conjunto de outras prescrições exigidas ao candidato ao episcopado, incluindo 0 adultério como pecado mediano:

Pecados grandes, e muy desaguisados son, segund lo departe Santa Eglesia, matar ome a sabiendas e de grado, o fazer simonía en Orden, o ser hereje. E los pecados medianos dizen que son estos, assi como adulterio, fornicio, falso testimonio, robo, furto, soberuia, auaricia, que se entiende por escasseza, saña de luengo tiempo, sacrilejo, perjuro, beodez cotidiana, engaño en dicho o en fecho, de que viene mal a otro. Pero si alguno faze destos pecados medianos, que auemos nombrado en esta ley, e lo conosce de su grado en pleyto para fazer enmienda del, non lo deuen desponer, mas deuele dar su Mayoral penitencia, qual entiende que meresce. Pero si fuer encubierto el pecado, desque ouiesse fecho penitencia del, non le

63 "E si por ventura algunos legos que non sean letrados, fueron tomados para Obispos en otro tiempo, aquello fue mas por miraglo de Dios, e por bondad que auia em ellos, que non por otra cosa". Cf. Primeira Partida (Gregório Lopez), Título V, Lei XXIII, p. 293-294. Na Lei XXIV, registra-se o seguinte: "o lego letrado, que non ouiesse embargo otro" poderia ser consagrado bispo. Cf. Primeria Partida (Gregório Lopez), Título V, Lei XXIV, p. 295.

"Verdaderamente con razon entendieron algunos la palabra que Sant Pablo, e porende fizieron departimiento entre los pecados muy grandes, e los medianos, e los menores, nombrando quantas maneras son, segund díze adelante. $\mathrm{E}$ dixeron, que el que fiziesse pecado muy grande ante que fuesse Obispo, quier fuere encubierto 0 manifiesto, maguer lo ouiesse confessado, que non lo podria despues ser. E aun encarescieron mas, que si el pecado fuesse manifiesto, e maguer el Obispo fuere elegido e ordenado, que deuia ser depuesto. Esto fizieron, porque mayor atreuimiento es en el pecado que se faze manifiesto, que en el encubierto, por el exemplo que toman ende los omes. Pero si el pecado fuesse encubierto, como quier que su Mayoral, despues que lo sopiesse, lo puede amonestar, e aun sosañar de parte de Dios, diziendole, que non se entremeta de auer aquel Obispado para que le eligieron con todo esso quanto por si mismo non le puede embargar, nin desechar, por saber el solamente que fizo el pecado. E si fiziesse pecado de los medianos, e aquel pecado fuese manifiesto, por juyzio que fmuesse dado contra el, o por conoscenciaq ue el ouiesse fecho en pleyto, o por miedo que gelo prouarian; o porque fuesse tan descubierto aquel fecho, que se non podiesse encubrir por ninguna manera, tal como este non deue ser elegido, e si lo fuer; deuenlo desponer. Mas si el pecado fuesse manifiesto por fama, e non se podria prouar, o si fuer acusado, e non se podria aueriguar por prueuas, si fallaren tales señales por que puedan sospechar contra el, estonce deuenlo mandar que se salue, segund aluedrio de su Perlado mayor". Cf. Primeria Partida (Gregório Lopez), Título V, Lei XXXII, p, 307-309. 
embarga para lo poder elegir, nin le pueden porende toller el logar que tiene..$^{67}$ (Grifos nossos)

Entre outras restrições, o bispo também não poderia ser ordenado prelado se sua mulher não recebesse o véu. A lei XXXVI aponta que "Otrosi, non puede ser elegido para Obispo, el que fuesse casado, si primeramente non entrasse en muger en Orden, faziendo prefession, e recebiendo el velo". 68 Como temos evidenciado, o que o discurso jurídico destaca é a falta de autonomia do sujeito e corpo femininos diante do que ocorreria com seus companheiros, isto é, as transformações sócio-jurídicas e eclesiásticas dos candidatos ao episcopado, supomos, de não ordenados para ordenados, implicariam no enclausuramento monacal das mulheres, o que pressupõe que a permanência dessas mulheres na vida leiga significaria algum tipo de irregularidade, infâmia ou desonra ao futuro ex-marido-bispo. 0 recado estava dado: ex-esposas de bispos não deveriam casar e gozar de liberdade conjugal, assim como deveriam seguir uma condição eclesiástica correspondente a nova condição do bispo, ou melhor, algo compatível ao seu gênero considerado não autônomo em relação ao ex-marido.

Os relacionamentos adulterinos constituíram outro fator de impedimento do acesso ao episcopado. Neste caso, isso valia tanto para o adultério associado à pessoa dos prelados como para os cometidos por suas mulheres.

[...] mas lo que sale del corazon, assi como furtos, homicidios, adulterios, pensamientos malos, e las otras cosas semejantes destas, esto ensuzia al ome, porque tuellen la buena fama. ${ }^{69}$

Esso mismo seria, si alguno casasse con muger, que cuydasse que era virgen, e non lo era: o seyendo casado con aquella que ouiesse virgen, fiziesse ella adulterio, e despues ouiesse el que ver con ella, sabiendolo. ${ }^{70}$

\section{Considerações finais}

\footnotetext{
67 Cf. Primeira Partida (Gregório Lopez), Título V, Lei XXXIII, p. 309-310.

68 Cf. Primeira Partida (Gregório Lopez), Título V. Lei XXXVI, p. 310-311.

69 Cf. Primeira Partida (Gregório Lopez), Título V, Lei LIII, p. 330.

70 Cf. Primeira Partida (Gregório Lopez), Título V. Lei XXXVI, p. 310-311.
} 
$\mathrm{O}$ que podemos concluir do que foi exposto até agora? As leis analisadas eram espécies de apropriações e ampliações adaptadas de legislações presentes em diversas tradições jurídicas romano-canônicas, especialmente as já contidas de alguma forma nos decretos de concílios diocesanos e nos concílios gerais (Latrão IV, por exemplo). A preocupação sistemática com a vida sexual dos clérigos não se resumiu simplesmente na divisão entre "clerigo o lego". Como ficou claro anteriormente, havia outros critérios que fraturavam e essencializaram as expectativas daquilo que se esperava daqueles que se dedicavam ao ofício eclesiástico. Havia uma crença de que a eficácia do ofício clerical só seria possível se e somente se seus oficiantes tivessem méritos comportamentais. Daí a preocupação com a fama e a infâmia clericais, especialmente sobre os crimes-pecados sexuais manifestos, já que o que estava em jogo era o potencial do clero para servir de suposto ou efetivo exemplo superior para o restante da sociedade. Na perspectiva das leis afonsinas, as diferenças entre clérigos e leigos conviviam com outras distinções entre clérigos ordenados ou não (ordens maiores e menores) e clérigos do Ocidente e do Oriente.

Para além de outras eventuais especificações, o gênero atuou no sentido de excluir total ou parcialmente no nível do discurso jurídico o acesso das mulheres às "Ordenes de Clerezia". Mas, além dessa constatação mais ou menos evidente, as diretrizes de gênero atuaram de uma forma muito mais sutil e, ao mesmo tempo, fundamental. Vimos que a legislação afonsina restringiu 0 intercurso sexual de clérigos com mulheres de uma maneira muito variável, tolerando-o ou restringindo-o partir de critérios muito diferentes e móveis conforme o "estado" do clérigo, mas também de acordo com as condições sócio-jurídicas das figuras femininas (concubinas, mancebas, "barraganas", esposas legítimas e virgens, esposas adúlteras, parentes, idosas, jovens).

Em parte, essa legislação posicionava-se legalmente diante daqueles clérigos que suposta ou efetivamente se aproximavam ou se distanciavam de uma espécie de ethos masculino, leigo e aristocrático no que tange ao comportamento sexual. As sexualidades em muitas sociedades medievais fundamentavam-se num conjunto paradigmático e teleológico, cujo fim era a reprodução e a criação de laços familiares. É possível que muitos clérigos adotassem e até desejassem ter uma vida conjugal semelhante a dos leigos da nobreza ou não, seguindo determinadas orientações ou horizontes comportamentais consagrados no período quanto à vivência das suas masculinidades. ${ }^{71}$ Ter filhos,

71 Uma hipótese semelhante foi aventada por Ana Rodrigues sobre a diocese portuguesa bracarense. Cf. RODRIGUES, A.M. Um mundo só de Homens: os capituralares bracarenses e a vivência da masculinidade nos finais da Idade Média, Estudos em homenagem ao professor doutor José Marques, Oporto, v. 1, v. 2, 2006, p. 195-209; Cf. também LEYSER, C. Masculinity in Flux... Op. cit., p. 103-120; SWANSON, R. N. Angels Incarnate: Clergy and 
vincular-se às mulheres, produzir e manter laços familiares, sustentando seus dependentes no que fosse preciso, eram formas ideais que nos parecem freqüentes no reino castelhano-leonês de meados do século XIII. Não consideramos que a filiação (reprodução), a vida conjugal com mulheres e 0 sustento das famílias extensas fossem um denominador comum das masculinidades hegemônicas medievais. Mas, pelo menos nos textos estudados, era isso que se desejava e, portanto, estava presente nas normatizações afonsinas. Do ponto de vista desta documentação, pautada significativamente pelas tradições jurídicas romano-canônicas, dada a freqüência de proibições e restrições à convivência de clérigos com mulheres, os papéis masculinos atribuídos aos clérigos constituem um problema a ser enfrentado por meio das leis. Os ideais masculinos e aristocráticos, por exemplo, deveriam ser relativizados, ordenados, deslocados e, conforme o caso, negados veementemente.

Dependendo da localização na hierarquia eclesiástica e conforme as diferentes condições sócio-jurídicas das figuras femininas, limitavam-se, restringiam-se ou até negavam-se determinadas práticas discursivas da paternidade e da parentalidade aos clérigos. Não foi casual que as Partidas tenham diferenciado a paternidade laica da clerical, justificando a variação hierárquica entre ordens menores e maiores e no seu interior. Ao se referir à importância do "ordenamiento de Santa Eglesia" e da autoridade patrística, na Lei II, Título VI, diz-se que "Santos Padres son llamados todos aquellos que fizieron el ordenamiento de Santa Eglesia". 72 Isso ocorreria por duas razões: "La vna, por que ellos fueron Santos en su vida, e en sus fechos. E la otra, porque frzieron ordenamientos santos. E Padres los llaman, porque crian los Christianos spiritualmente con el santo ordenamiento sobredicho, assi como los padres temporales crian sus fijos. Ellos fizieron departimiento entre los Clerigos". $(\text { Grifos nossos) })^{73}$

Admite-se, portanto, um papel provedor tanto para os pais-leigos ("padres temporales") como também para os "santos padres", provedores em uma filiação moral e religiosa, mas isso é feito apropriando-se de um discurso sobre o prestígio parental masculino e deslocando-se ligeiramente a imagem de paternidade consagrada para uma diferenciação hierárquica estabelecida entre o espiritual e o temporal. Obviamente, atribui-se um valor superior do primeiro diante do segundo. Dentro da hierarquia oficial da Santa Igreja, haveria pais tão provedores quanto quaisquer figuras paternas do

Masculinity from Gregorian Reform to Reformation. In: HADLEY, D. M. Masculinity in Medieval Europe, London/New York, Longman, 1999, p. 161. 
mundo temporal, mas essa paternidade não seria só deste mundo e não produziria e criaria filhos comuns, já que se trataria em um só tempo de filhos-fiéis-cristãos.

Como sugerimos antes, apesar da legislação reconhecer uma série de direitos femininos (demanda pelo débito conjugal, a possibilidade de continuar convivendo sob a dependência clerical, o consentimento para o marido se ordenar, viver com clérigos não ordenados etc.), o tratamento dado às figuras femininas foi assimétrico quanto às suas condições sócio-jurídicas (vassalas ou servas), quanto à idade (jovens ou idosas), ao vinculo conjugal (casadas ou não), ao grau de parentesco etc., estipulando o afastamento ou, para alguns casos, a imposição da clausura e da castidade para as esposas legítimas de clérigos ordenados depois do casamento. Em parte, na ótica de uma sexualidade teleológica, leiga e aristocrática, voltada para a reprodução e a criação de laços familiares, será que a legislação afonsina funcionava como um esforço jurídico em prol de uma espécie de "desmasculinização" ou uma "feminilização" articulada a um esforço de, com o perdão da expressão redundante, "clericalizar os clérigos", seguindo as diferentes expectativas que se tinha conforme os graus hierárquicos? ${ }^{74}$ Isto era uma possibilidade, mas temos que problematizar melhor esse aspecto, levando em conta se as legislações afonsinas respondiam ou não ao jogo de "hipomasculinidades" ou, como diria Miller, de "hipermasculinidades" vigentes e associadas aos diferentes clérigos. ${ }^{75}$

Mas não consideramos uma asserção possível a hipótese ventilada por Gilbert Herdt quando associa anacronicamente os clérigos medievais a "terceiros sexos" ou a "terceiros gêneros". 76 Pelo contrário, mesmo levando-se em conta o peso considerável dado ao binarismo para as formulações discursivas medievais sobre as "personas" jurídicas, não podemos perder de vista que se tratava muito mais de uma multiplicidade de masculinidades em disputa, em duelo, do que um simples dimorfismo ambígua e estavelmente situado entre o feminino e o masculino. A ótica jurídica afonsina não era a única nem a definitiva, embora quisesse tornar hegemônica sua proposta naturalizada de "masculininidade ascética" para o clero. Mas isso se deu de forma variável e complexa, (des)articulando-se com outros critérios sócio-eclesiásticos, religiosos, morais, intelectuais, sócio-

Cf. MILLER, M. Masculinity, reform, and clerical culture: narratives of episcopal holiness in the Gregorian Era. Church History, v. 72, n.1, março/2003, p. 25-52.

Cf. HERDT, G. Introduction. In: Third sex, third gender. beyond sexual dimorphism in culture and history. New York: Zone Books, 1993, p. 21-81. Sobre a historicidade da categoria "terceiro sexo" desde o século XIX ver $\mathrm{NUCCl}, \mathrm{M}$. F.; RUSSO, J. A. 0 terceiro sexo revisitado: a homossexualidade no Archives of Sexual Behavior. Physis, v.19, n.1, 2009, p. 127-147. Cf também FAUSTO-STERLING, A. Dualismos em duelo. Cadernos Pagu, Campinas, n. 17/18, p. 9-79, 2002. 
jurídicos e "genderizados". Talvez, não seria forçoso dizer que as Partidas deixavam implícito um ideal múltiplo e complexo de masculinidades variáveis conforme os graus de clericalização dos membros da hierarquia da Igreja.

Em se tratando do processo de criminalização do adultério como pecado-crime-erro, sua força potencialmente disruptiva funcionava em sentido semelhante. Ao mesmo tempo em que se negava ou se restringia a parentalidade temporal, a prática sexual, a busca de laços familiares e a obtenção de filhos (paternidade temporal), que eventualmente herdassem seus ofícios, bens e dignidades, a legislação afonsina também regulamentava os casos de clérigos ordenados que agiam como leigos em relações extraconjugais, afetando a honra de maridos alheios.

\section{Bibliografia}

\section{Documentos Impressos:}

ALFONSO X. Las Siete Partidas de Don Alfonso X. Barcelona: Impresta de Antonio Bergnes, 1843-1844. Disponível na Internet via < http://fama.us.es/search ${ }^{*}$ spi/c?SEARCH=a+mont. $+11+1+15>$. Acesso em março de 2013.

ARIAS BONET. J.A. Primeira Partida. Manuscrito Add. 20.787 del British Museum. Valladolid: Universidad de Valladolid, 1975.

BERNÍ Y CATALÁ, J. Las siete partidas... Edición de Valencia: Imprenta de Benito Monfort, 1767. Edição disponível na Biblioteca Virtual de Pensamiento Político Hispânico Saavedra Fajardo via <http://saavedrafajardo.um.es/WEB/HTML/iniciop.html?Open>. Acesso em março de 2013.

BOSSINI, F.R. Primeira Partida (MS.HC.397/573). Hispanic Society of América. Granada: Caja General de Ahorros y Monte de Piedad de Granada, 1984.

FOREVILLE, R. Lateranense I, II y III. Ed. Eset, 1972.

FOREVILLE, R. Lateranense IV. Vitoria: Ed. Eset, 1972.

VANDERFORD, K. H. Setenario. Facultad de Filosofía y Letras de la Universidad de Buenos Aires, Buenos Aires, 1945.

\section{Referências bibliográficas:}

ALONSO, M. Diccionario medieval español. Desde las glosas emilianenses y silenses (s.X) hasta el siglo XV. Tomo I e II, Salamanca: Universidad Pontificia de Salamanca: Imprenta Kadmos, 1986. 
ALVARO, B. G. A construção das masculinidades em Castela no século XIII: um estudo comparativo do poema de Mio Cid e da vida de Santo Domingo de Silos. Dissertação de mestrado apresentada ao PPGHC em 2008. Disponivel na Internet via < http://teses2.ufri.br/Teses/IFCS_M/BrunoGoncalvesAlvaro.pdf>. Acesso em 2013.

ARRANZ GUSMÁN, A. Amores desordenados y otros pecadillos del clero. In: CARRASCO MANCHADO, A.l.; RÁBADE OBRADÓ, M.P. (Coords). Pecar en la Edad Media. Madrid; Sílex, 2008.

BADINTER, E. Um é o outro. Rio de Janeiro: Nova Fronteira, 1986.

BEAUDETTE, P. In the world but not of it: Clerical celibacy as a symbol of the medieval church. In: FRASSETTO, M. (ed.). Medieval Purity and Piety. Essays on medieval clerical celibacy and religious reform. New York: London, Garland Publishing, 1998, p. 24-27.

BOURDIEU, P. (1995). A dominação masculina. Educação \& Realidade (v.20,n.2), p. 133-84.

BRADY, S.; ARNOLD, J. (Eds). What is masculinity? Historical dynamics from Antiguity to the Contemporary World. Great Britain: Palgrave Macmillan, 2011.

CECCARELLI, P. R. A construção da masculinidade, Percurso, São Paulo, Vol. 19, 1998, p.49-56.

CULLUM, P.H.; LEWIS, K.J. Holi ness and masculinity in the Middle Ages. University of Wales Press: Cardiff, 2004.

DAMATTA, R. Tem pente aí?: reflexões sobre a identidade masculina. In: CALDAS, D. (org). Homens. São Paulo: Ed. Senac, 1997.

ELLIOTT, D. Conjugal Dept and Vows of Chastity. In: Spiritual Marriage: sexual abstinence in medieval wedlock. Priceton, New Jersey: Priceton University Press, 1993, p. 151-152.

FAUSTO-STERLING, A. Dualismos em duelo. Cadernos Pagu, Campinas, n. 17/18, 2002, p. 9-79.

FRAZÂO. A.C.L.F. "Reflexões sobre o uso da categoria gênero os estudos de História Medieval no Brasil (19902003)". Caderno Espaço Feminino, v.11, n14, jan.jjul., 2004, p. 87-107.

FREYRE, G. Modos de homem. Modas de mulher. Rio de Janeiro: Record, 1986.

GOLDENBERG, M. A Outra: estudos antropológicos sobre a identidade da amante do homem casado. Rio de Janeiro: Record, 1997.

GOLDENBERG, M. Masculinidade em crise: novos modelos de "ser homem". Disponível na Internet $<$ http://miriangoldenberg.com.br/content.php?option=com content\&task=view\&id=29\&ltemid=95>. Acesso em abril de 2013.

GOLDENBERG, M. Os Novos Desejos. Rio de Janeiro: Record, 2000; KIMMEL, M. A produção simultânea de masculinidades hegemônicas e subalternas. Horizontes antropológicos 9 (4), 1998, p. 103-17.

GOLDENBERG, M. Ser homem, ser mulher: dentro e fora do casamento. Rio de Janeiro: Revan, 1991.

GROSSI, M.P. Masculinidades: uma revisão teórica. São Paulo: Mandrágora, a. XII, n. 12 , 2006, p. 21-42.

GRYSON, R. Les Origines du Célibat Ecclésiastique du premier au septième siècle, Gembloux: Duculot, 1970, p. 197-198. 
HADLEY, D. M.(Ed.) Masculinity in medieval Europe. London, New Yok, Longman: Editor-Dawn Hadley, 1999.

HERDT, G. Introduction. In: ___. Third sex, third gender: beyond sexual dimorphism in culture and history. New York: Zone Books, 1993, p. 21-81.

KARRAS, R. M. From boys to men: formations of masculinity in the medieval Europa. Philadelphia, Pennsylvania: University of Pennsylvania Press, 2003.

KIMMEL, M. \& MESSNER, M. Men's Lives. Boston, Allyn and Bacon, 1994.

KLAPISH-ZUBER, C. Masculino/feminino.In: LE GOFF, J.; SCHMITT, J-C. Dicionário Temático do Ocidente Medieval , v.1, Bauru, SP; Edusc, São Paulo, SP, Imprensa Oficial do Estado, 2002, p. 137-150.

LEES, C.A. (Ed.)Medieval Masculinities: regarding men in the Middle Ages, Minneapolis: University of Minnesota Press, 1994.

LEYSER, C. Masculinity in Flux: Nocturnal Emission and the Limits of Celibacy in the Early Middle Ages, Hadley,

D. M. Masculinity in Medieval Europe, London/New York, Longman, 1999, p. 110-112.

LIMA, M.P. Ciência política, medievalismo e estudos de gênero: a propósito das relações de poder no reino castelhano-leonês, séc. XIII. Atas da VII Semana de Estudos Medievais do Programa de Estudos Medievais da UFRJ, 28 a 30 de novembro de 2007. Rio de Janeiro: março de 2008, p. 116-123.

LIMA, M.P. Do pecado ao gênero da confissão religiosa: algumas reflexões sobre as concepções de pessoa na legislação afonsina, século XIII, Revista Signum, v. 11, 2010, p. 236-266.

LIMA, M.P.; FRAZÃO, A.C.L. Gênero e vida religiosa feminina nas Siete Partidas. Revista Territórios e Fronteira, v. 1, n.2, jul./dez, 2008, p 46-68.

LOPES, C.R.R. A construção do ideal de masculinidade na sociedade ibero-castelhana do século XIII. Fazendo Gênero 8. Corpo, Violência e Poder. Disponível na Internet via < http://www.fazendogenero.ufsc.br/8/simposios.html>. Acesso em maio de 2013.

MLLLER, M. Masculinity, reform, and clerical culture: narratives of episcopal holiness in the Gregorian Era. Church History, v. 72, n.1, março/2003, p. 25-52.

MURRAY, M. The law of the father: patriarchy in the transition from feudalism to capitalism. London, New York: Taylon \& Francis e-Library, 2005.

NUCCI, M. F.; RUSSO, J. A. O terceiro sexo revisitado: a homossexualidade no Archives of Sexual Behavior. Physis, v.19, n.1, 2009, p. 127-147.

OLIVEIRA, P. P. A construção social da masculinidade. Belo Horizonte: Editora UFMG, Rio de Janeiro: IUPERJ, 2004.

PÉROTIN-DUMON, A. Masculinidad. In: El género en historia, Institute of Latin American Studies, University of London, 2001. Disponivel na Internet via< http://americas.sas.ac.uk/publications/genero/genero_portada.htm>. Acesso em abril de 2013.

RAMOS, M. S. Um olhar sobre o masculino: reflexões sobre os papéis e representações sociais do homem na atualidade. In: GOLDENBERG, M. (org). Os Novos Desejos. Rio de Janeiro: Record, 2000. 
RODRIGUES, A.M. Um mundo só de Homens: os capituralares bracarenses e a vivência da masculinidade nos finais da Idade Média, Estudos em homenagem ao professor doutor José Marques, Oporto, v. 1, v. 2, 2006, p. 195-209.

SCHMITT, J-C. Clérigos e leigos. In: LE GOFF, J.; SCHMITT, J-C. Dicionário Temático do Ocidente Medieval, v.1, Bauru, SP; Edusc, São Paulo, SP, Imprensa Oficial do Estado, 2002.

SILVA, S. G. A crise da Masculinidade: uma crítica à identidade de Gênero e à Literatura Masculinista. Psicologia, Ciência e Profissão, 2006, 26 (1), 118-131.

SILVA, S. G.. Masculinidade na História, Psicologia, Ciência e Profissão, 2000, 20 (3), 8-15.

STICKLER, A. M. L'évolution de la discipline du célibat dans l'Eglise en Occident de la fin de l'âge patristique au concile de Trente. In: COPPENS, J.. Sacerdoce et Célibat. Etudes Historiques et Théologiques. Louvain, Ed. Peeters, 1971, p. 373-375.

STONE, R. Morality and masculinity in the Carolingian empire. United Kingdom: Cambridge University Press, 2012.

SWANSON, R. N. Angels Incarnate: Clergy and Masculinity from Gregorian Reform to Reformation. In: HADLEY, D. M. Masculinity in Medieval Europe, London/New York, Longman, 1999.

TEJADA Y RAMIRO, J. Colección de cânones y todos los concilios de la Iglesia de España y America. Madrid: Imprenta de D. Pedro Montero, 1861, Tomo III.

UBITEL, L.; LIFSHTZ, F. Gender and Chistianity in medieval Europe; new perspectives. Philadelphia, Pennsylvania: University of Pennsylvania Press, 2008. 